\title{
The effects of the standardized extracts of Ginkgo biloba on steroidogenesis pathways and aromatase activity in H295R human adrenocortical carcinoma cells
}

\author{
Mijie Kim ${ }^{1}$, Yong Joo Park ${ }^{2}$, Huiyeon Ahn³ ${ }^{3}$ Byeonghak Moon ${ }^{3}$, Kyu Hyuck Chung ${ }^{2}$, \\ Seung Min $\mathrm{Oh}^{3}$ \\ ${ }^{1}$ Oncology and Antimicrobial Products Division, National Institute of Food and Drug Safety Evaluation, Cheongju; ${ }^{2}$ School of \\ Pharmacy, Sungkyunkwan University, Suwon; ${ }^{3}$ Department of Nanofusion Technology, Hoseo University, Asan, Korea
}

\begin{abstract}
Objectives Aromatase inhibitors that block estrogen synthesis are a proven first-line hormonal therapy for postmenopausal breast cancer. Although it is known that standardized extract of Ginkgo biloba (EGb761) induces anti-carcinogenic effects like the aromatase inhibitors, the effects of EGb761 on steroidogenesis have not been studied yet. Therefore, the effects of ECb76r on steroidogenesis and aromatase activity was studied using a H295R cell model, which was a good in vitro model to predict effects on human adrenal steroidogenesis.

Methods Cortisol, aldosterone, testosterone, and $17 \beta$-estradiol were evaluated in the $\mathrm{H} 295 \mathrm{R}$ cells by competitive enzyme-linked immunospecific assay after exposure to ECb761. Real-time polymerase chain reaction were performed to evaluate effects on critical genes in steroid hormone production, specifically cytochrome P450 (CYP11/ 17/19/21) and the hydroxysteroid dehydrogenases $(3 \beta-\mathrm{HSD} 2$ and $17 \beta-\mathrm{HSD} 1 / 4)$. Finally, aromatase activities were measured with a tritiated water-release assay and by western blotting analysis. Results $\mathrm{H}_{295 \mathrm{R}}$ cells exposed to ECb761 (10 and $100 \mu \mathrm{g} / \mathrm{mL}$ ) showed a significant decrease in $17 \beta$-estradiol and testosterone, but no change in aldosterone or cortisol. Genes (CYP19 and $17 \beta-H S D 1)$ related to the estrogen steroidogenesis were significantly decreased by ECb761. ECb761 treatment of $\mathrm{H}_{295} \mathrm{R}$ cells resulted in a significant decrease of aromatase activity as measured by the direct and indirect assays. The coding sequence/Exon PII of CYP19 gene transcript and protein level of CYP19 were significantly decreased by ECb761.

Conclusions These results suggest that ECb76r could regulate steroidogenesis-related genes such as CYP19 and $17 \beta-\mathrm{HSD}$, and lead to a decrease in $17 \beta$-estradiol and testosterone. The present study provides good information on potential therapeutic effects of EGb761 on estrogen dependent breast cancer.
\end{abstract}

Keywords Ginkgo biloba extracts, Aromatase inhibitor, H295R cells, Steroidogenesis
Correspondence: Seung Min Oh 20 Hoseo-ro 79 beon-gil, Baebang-eup,

Asan 31499, Korea

Tel: +82-41-540-9697

Fax: +82-47-540-9697

E-mail:ohsmo403@hoseo.edu

Received: March 17, 2016

Accepted: April 14, 2016

Published: May 9, 2016

This article is available from: http://e-eht.org/ 


\section{Introduction}

Breast cancer is the most common disease for women in Korea [1]. Because estrogens are the main determinants in breast cancer, aromatase, the key enzyme of estrogen synthesis, has been considered one of the most important enzymes among the steroidogenesis enzymes [2,3]. Therefore, aromatase inhibitors (AIs) such as anastrozole, letrozole, and exemestane are used to treat breast cancer by depleting estrogen $[3,4]$. However, although AIs have been proven as a standard endocrine therapy medicines based on large clinical trials, they have limitations because of their side effects, which include bone fracture, bone loss, and musculoskeletal events [5]. These limitations of synthetic medicines have spurred efforts to search for new compounds that could be effective at tolerable doses without adverse effects [6].

Ginkgo biloba is a tree that has been used in traditional Chinese medicine for about 5000 years and is now commercially cultivated in France and the US [7]. Previous studies reported that Ginkgo biloba extract (EGb) has a biphasic effect on estrogen activity $[8,9]$ and bone density through osteoblastic and anti-osteoclastic effects [10]. EGb and its major constituents (quercetin and kaempferol) were reported to regulate estrogen levels as aromatase inhibitors $[11,12]$. In addition, Park et al. [13] elucidated that standardized extract of Ginkgo biloba (EGb761) could induce anti-carcinogenic effects on breast cancer as the aromatase inhibitors. However, the effects of EGb761 on entire steroidogenesis pathways (aldosterone, cortisol, testosterone, and $17 \beta$-estradiol synthesis) have not been studied yet. Therefore, in this study, the effects of EGb761 on steroidogenesis pathways and aromatase activities were evaluated.

In postmenopausal women, the steroidogenic enzymes are mainly expressed in the adrenal glands, which are the main source of estrogens. The human H295R adrenocortical carcinoma cells have the physiologic features of zonally undifferentiated human fetal adrenal cells and express all the steroidogenic enzymes essential for steroid hormone synthesis in the adult adrenal cortex [14]. As such, the H295R cell line has been used broadly as an in vitro model to predict effects on human adrenal steroidogenesis $[15,16]$. In this study, the H295R cell model was used to evaluate effects of EGb761 on steroidogenesis pathways. First, a cell viability test was carried out to find the appropriate dose-range of EGb761 without cytotoxicity. Second, levels of four steroid hormones including cortisol, aldosterone, testosterone, and $17 \beta$-estradiol, were measured by competitive enzyme-linked immunospecific assay (ELISA). Third, the genes required for steroid hormone production including steroidogenic acute regulatory protein (StAR), cytochrome P450
(CYP11, CYP17, CYP19, and CYP21), and the hydroxysteroid

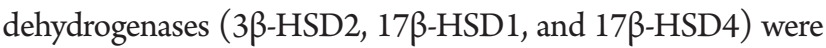
quantified by real-time polymerase chain reaction (PCR). Finally, aromatase activity was measured with a tritiated water release assay and protein levels were measured by western blotting.

\section{Materials and Methods}

\section{Cell Culture}

H295R human adrenocarcinoma cells (CRL-2128) were purchased from the American Type Culture Collection (Fairfax, VA, USA) and cultured as a monolayer in H295R supplemented media, which is a 1:1 mixture of Dulbecco's modified Eagle's medium and Ham's F-12 nutrient mixture (DMEM/F12) (Sigma-Aldrich, St. Louis, MO, USA) containing 1\% ITS + Premix (BD Biosciences, San Diego, CA, USA), 2.5\% Nu-Serum (BD Biosciences), $1.2 \mathrm{~g} / \mathrm{L} \mathrm{Na}_{2} \mathrm{CO}_{3}$ (Sigma-Aldrich), and $1 \%$ penicillin-streptomycin (GibcoBRL, Grand Island, NY, USA). Cells were cultured in a humidified environment at $37^{\circ} \mathrm{C}$ containing 95\% air/5\% carbon dioxide. Medium was changed three times a week and cell subculture was performed every seven days.

\section{Test Chemicals}

The EGb761 were kindly provided and standardized by YuYu Pharma Inc. (Seoul, Korea). The EGb761 contained 24.7\% flavones glycosides (including quercetin, kaempferol, and isorhamnetin) and $6.1 \%$ terpene lactones (3.2\% ginkgolides and $2.9 \%$ bilobalide), which represent the major active components of EGb761. The solution was prepared in 50\% ethanol/water at $250 \mathrm{mg} / \mathrm{mL}$. Dimethyl sulfoxide (DMSO) was purchased from Sigma-Aldrich. The radioactive solution, $\left[1 \beta-{ }^{3} \mathrm{H}\right]$ androst4-ene-3,17-dione, was purchased from PerkinElmer ${ }^{\circledR}$ (Waltham, MA, USA).

\section{Cell Viability Test}

To evaluate cell viability and to exclude cytotoxic concentration ranges of EGb761, the cells were seeded onto 96-well plates at a density of 10000 cells/well with $200 \mu \mathrm{L}$ of medium. After incubation with EGb761 (from one to $1000 \mu \mathrm{g} / \mathrm{mL}$ ) for 24 hours, cell viability was measured by the WST-1 assay (Roche, Mannheim, Germany).

\section{Hormone Measurement (Aldosterone, Cortisol, Testosterone, and $17 \beta$-estradiol)}

Cells were seeded into 24 -well plates at a density of $30 \times 10^{4}$ cells $/ \mathrm{mL}$ in $1 \mathrm{~mL}$ of medium per well. After 24 hours, the cells were exposed to EGb761 (10 and $100 \mu \mathrm{g} / \mathrm{mL}$ ) for 24 hours. In instances where exposure resulted in cell viability of less than 
$85 \%$, the cells were not used for the evaluation of hormone production [17]. Hormones were measured by competitive ELISA following the manufacturer's recommendations (Cayman Chemical, Ann Arbor, MC, USA; aldosterone [Catalog no. 1004377], cortisol [Catalog no. 500360], testosterone [Catalog no. 582701], and $17 \beta$-estradiol [Catalog no. 582251]). The detection limit of aldosterone, cortisol, testosterone, and $17 \beta$-estradiol were 24.02 , $14.97,11.71$, and $22.75 \mathrm{pg} / \mathrm{mL}$, respectively.

\section{Quantitative Real-time Polymerase Chain Reaction on Genes Related to Steroidogenesis in H295R Cells}

To characterize the regulation of gene expression in cells, we performed real-time PCR using specific sense and anti-sense primers, in order to check the mRNA expression levels. Total RNA was purified from cells exposed to EGb761 (10 and 100

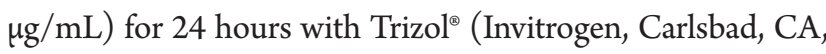
USA). cDNA was synthesized from $2 \mu \mathrm{g}$ of total RNA using AMV reverse-transcriptase (Promega, San Luis Obispo, CA, USA) in a $20 \mu \mathrm{L}$ reaction. Quantitative real-time PCR reaction mixtures $(15 \mu \mathrm{L})$ contained $1 \mu \mathrm{L}(0.1 \mu \mathrm{M})$ of forward and reverse primers, $3 \mu \mathrm{L}$ of cDNA sample, and $7.5 \mu \mathrm{L}$ of $2 x$ SYBR Green $^{\text {Tx }}$ PCR Master Mix. The following thermal cycle profile was used: denaturing at $94^{\circ} \mathrm{C}$ for 10 minutes, followed by $40 \mathrm{cy}$ cles of denaturing for 15 seconds at $94^{\circ} \mathrm{C}$, annealing with extension at $60^{\circ} \mathrm{C}$ to $64^{\circ} \mathrm{C}$ (Table 1) for one minute, $72^{\circ} \mathrm{C}$ for $30 \mathrm{sec}-$ onds, respectively, and a final cycle of $94^{\circ} \mathrm{C}$ for 15 seconds, $50^{\circ} \mathrm{C}$ for one minute, and $94^{\circ} \mathrm{C}$ for 15 seconds. The primer sequences were synthesized by Bioneer (Daejeon, Korea) and are shown in Table 1. Expression levels of mRNA were quantified by use of the threshold cycle $(\mathrm{Ct})$ method. Ct values for each gene of interest were normalized to $\beta$-actin.

\section{'In-cell' Aromatase Activity Assay - Tritiated Water- Release Assay}

Indirect and direct effects on aromatase activity were measured using a tritiated water-release assay as described by Leph- art and Simpson [18] with minor modifications. This assay was performed by measuring the amount of $\left[{ }^{3} \mathrm{H}\right] \mathrm{H}_{2} \mathrm{O}$ released upon the conversion of $\left[1 \beta-{ }^{3} \mathrm{H}\right]$ androst-4-ene-3,17-dione to estrone $[18,19]$. Cells were plated in 24-well plates with growth media and exposed to EGb761 (10 and $100 \mu \mathrm{g} / \mathrm{mL}$ ) in the incubation media after cells were $80 \%$ confluent. The incubation media were prepared in $0.1 \%(\mathrm{v} / \mathrm{v})$ ethanol in H295R supplemented media for H295R cells. The experiments were conducted in three different ways: (1) Indirect aromatase activity: cells plated in 24-well plates were exposed to EGb761 (10 and 100 $\mu \mathrm{g} / \mathrm{mL}$ ) for 24 hours and then the cells were incubated in 0.25 $\mathrm{mL}$ of supplemented medium containing $54 \mathrm{nM}\left[1 \beta-{ }^{3} \mathrm{H}\right]$ androst-4-ene-3,17-dione (PerkinElmer ${ }^{\circledR}$ ) for 2 hours; (2) Direct aromatase activity: untreated cells were exposed to EGb761 (10 and $100 \mu \mathrm{g} / \mathrm{mL}$ ) while a 2 hours tritium-release assay was conducted to assess direct interaction with the enzyme. Aromatase enzyme activity was measured as described by Kim et al. [11].

\section{Western Blot Analysis}

Protein from the cells exposed to EGb761 (10 and $100 \mu \mathrm{g} /$ $\mathrm{mL}$ ) was extracted with radioimmuno-precipitation assay (RIPA; Thermo Scientific, Rockford, IL, USA) buffer containing $1 \%$ protease inhibitor cocktail solution (GenDEPOT, Houston, TX, USA). Lysate proteins ( $50 \mu \mathrm{g})$ denatured with $2 \mathrm{x}$ sample buffer (Bio-RAD, Hercules, CA, USA) were separated by $10 \%$ sodium dodecyl sulfate-polyacrylamide gel electrophoresis and transferred onto nitrocellulose blotting membranes. Immunodetection was performed using anti-aromatase (1:1000, abcam35604, Abcam Plc, Cambridge, UK) and anti-actin antibodies (1:4000, 13E5, Cell Signaling Technology, Danvers, MA, USA), respectively. The corresponding anti-rabbit horseradish peroxidase (HRP) conjugated secondary antibody (Abcam $\mathrm{Plc}$ ) was used. An ECL ${ }^{\text {plus }}$ detection kit (Thermo Fisher Scientific Inc., Rockford, IL, USA) provided the chemiluminescence substrate for HRP, and the targeted protein was visualized by autoradiography.

Table 1.Conditions for quantitative reverse-transcriptase polymerase chain reaction

\begin{tabular}{|c|c|c|c|c|}
\hline Gene & Amplicon size (bp) & $\begin{array}{l}\text { Annealing temperature } \\
\qquad\left({ }^{\circ} \mathrm{C}\right)\end{array}$ & Forward primer $\left(5^{\prime} \rightarrow 3^{\prime}\right)$ & Reverse primer $\left(5^{\prime} \rightarrow 3^{\prime}\right)$ \\
\hline$\beta$-actin & 100 & 64 & САСТCTTCCAGСCTTCCTTCC & AGGTCTTTGCGGATGTCCAC \\
\hline CYP11A & 137 & 62 & GAGATGGCACGCAACCTGAAG & СTTAGTGTCTCCTTGATGCTGGC \\
\hline CYP11B1 & 541 & 62 & GGCAGAGGCAGAGATGCTG & TCTTGGGTTAGTGTCTCCACCTG \\
\hline CYP11B2 & 146 & 62 & TCCAGGTGTGTTCAGTAGTTCC & GAAGCCATCTCTGAGGTCTGTG \\
\hline CYP17A1 & 134 & 64 & AGCCGCACACCAACTATCAG & TCACCGATGCTGGAGTCAAC \\
\hline CYP19 & 128 & 64 & AGGTGCTATTGGTCATCTGCTC & TGGTGGAATCGGGTCTTTATGG \\
\hline CYP21A2 & 108 & 64 & CGTGGTGCTGACCCGACTG & GGCTGCATCTTGAGGATGACAC \\
\hline $3 \beta-H S D 2$ & 95 & 60 & TGCCAGTCTTCATCTACACCAG & TTCCAGAGGCTCTTCTTCGTG \\
\hline 17 $\beta$-HSD1 & 136 & 64 & СTCССTCTGACCAGCAACC & TGTGTCTCCCACGCAATCTC \\
\hline $17 \beta-H S D 4$ & 121 & 62 & TGCGGGATCACGGATGACTC & GCСАССАТTCTССTСАСААСТC \\
\hline
\end{tabular}




\section{Statistical Methods}

SigmaPlot version 12.0 (Jandel Scientific, San Rafael, CA, USA) and Excel 2013 (Microsoft Co., Redmond, WA, USA) were used to analyze the data. The data from each assay were expressed as mean \pm standard deviation. Statistical analysis was performed using the SPSS version 18.0 (SPSS Inc., Chicago, IL, USA) program. Differences between groups were tested by Duncan's post-hoc test following a one-way analysis of variance (ANOVA). Statistical significance was accepted at $p<0.05$.

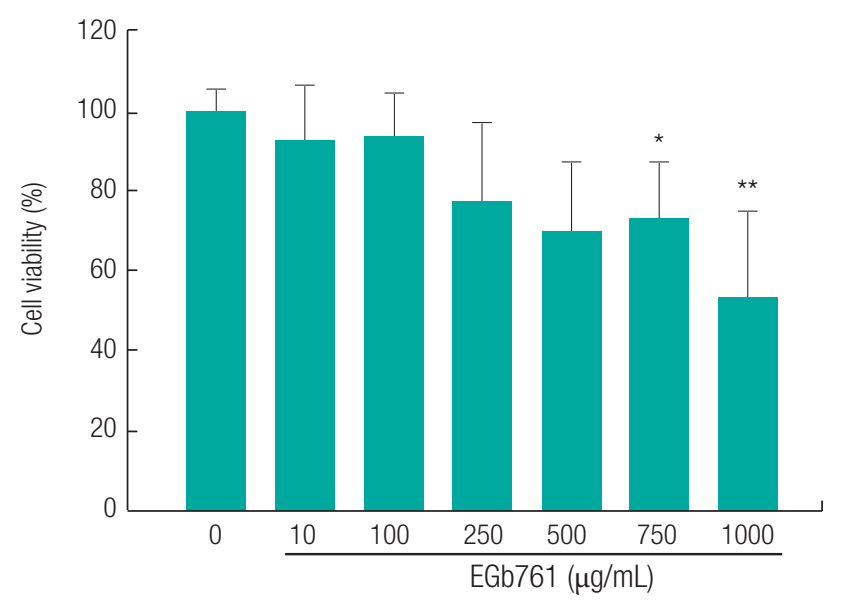

Figure 1. The cell viability following standardized extract of Ginkgo biloba (EGb761) treatment of H295R cells. The WST-1 assay was used to evaluate cell viability and exclude cytotoxic concentrations of EGb761. The cells were seeded and incubated for 24 hours, and various concentrations of EGb761 were added. After 24 hours of incubation, the medium was removed and the WST-1 reagent was added to each well. The absorbance was measured at a wavelength of $440 \mathrm{~nm}$ with a reference wavelength of $690 \mathrm{~nm}$. The results are expressed as the mean \pm standard deviation of three separate experiments. Values are significantly different from the control: ${ }^{*} p<0.05,{ }^{* *} p<0.01$.

\section{Results}

\section{Cell Viability Effects of Standardized Extract of Ginkgo biloba}

Since cytotoxic concentrations should be excluded from the experiments, we first evaluated cell viability following exposure to various concentrations of EGb761 with the WST-1 assay. Cell viability was significantly inhibited at 750 and $1000 \mu \mathrm{g} / \mathrm{mL}$ EGb761. The observed viability was greater than $85 \%$ in the EGb761 concentration range of 10 to $100 \mu \mathrm{g} / \mathrm{mL}$ (Figure 1), which then was chosen as the concentration range to be used in

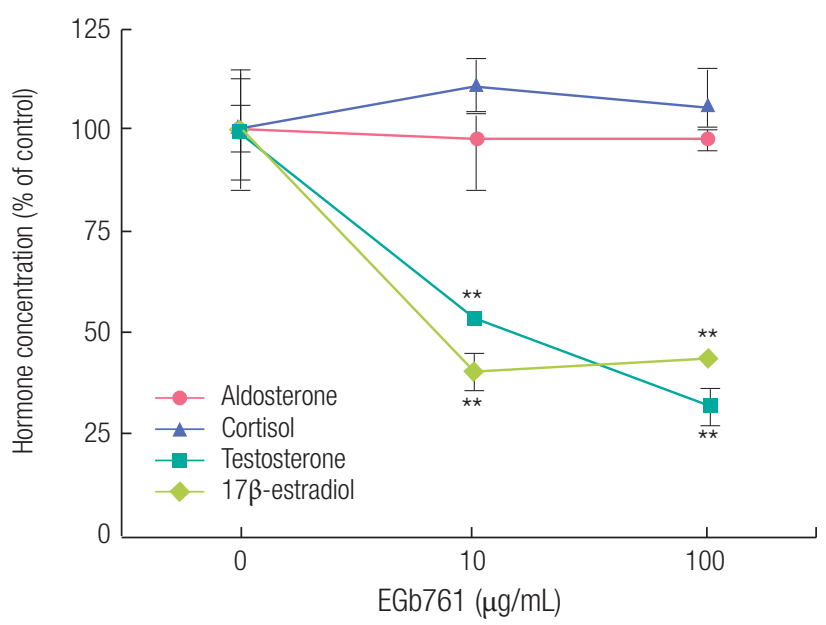

Figure 2. Standardized extract of Ginkgo biloba (EGb761)-dependent changes in aldosterone, cortisol, testosterone, and 17 $\beta$-estradiol concentrations in H295R cells. Adherent cells were exposed to EGb761 (10 and $100 \mu \mathrm{g} / \mathrm{mL}$ ) for 24 hours. Hormone concentrations were measured by competitive enzyme-linked immunospecific assay following the manufacturer's recommendations. The results are expressed as the mean \pm standard deviation of three separate experiments for each group. Values are significantly different from the control: ${ }^{* *} p<0.01$. Hormone basal level: aldosterone $(136.16 \pm 6.94 \mathrm{pg} / \mathrm{mL})$; cortisol $(2014.62 \pm 149.32 \mathrm{pg} / \mathrm{mL})$; testosterone (182.25 $\pm 25.79 \mathrm{pg} / \mathrm{mL}) ; 17 \beta$-estradiol $(181.48 \pm 27.46 \mathrm{pg} / \mathrm{mL})$.
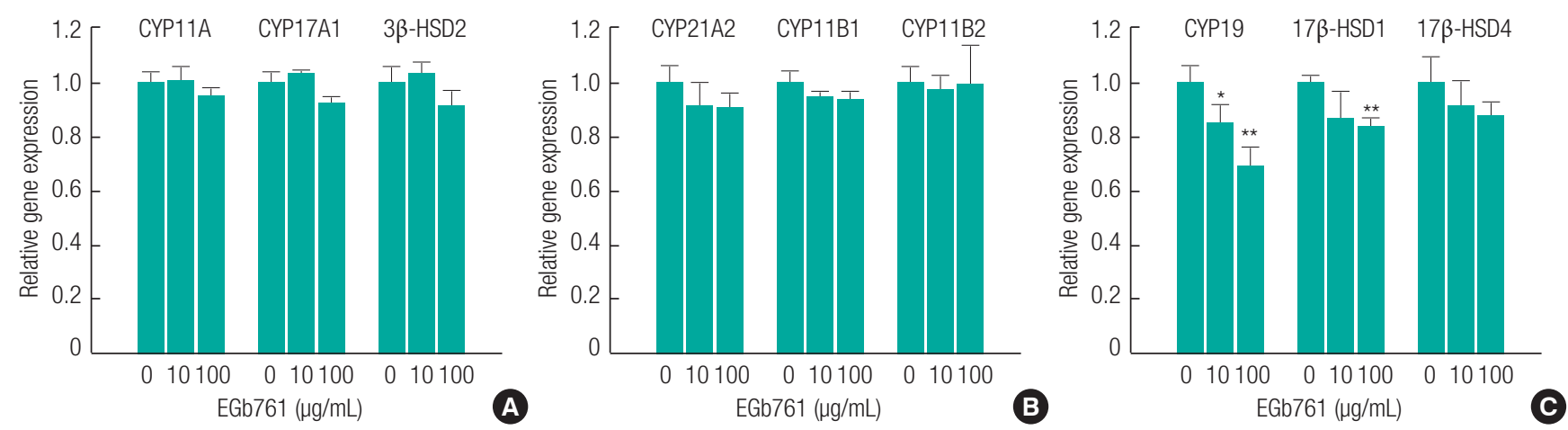

Figure 3. The effects of standardized extract of Ginkgo biloba (EGb761) on the expression of genes related to steroidogenesis pathways in H295R cells. Adherent cells were exposed to various concentration of EGb761 (10 and $100 \mu \mathrm{g} / \mathrm{mL}$ ) for 24 hours. Total RNA was isolated from cells using Trizol. Gene specific primers (see Table 1) were used to quantify mRNA levels using real-time polymerase chain reaction. Relative mRNA levels were normalized to $\beta$-actin mRNA level. Relative mRNA expression was calculated as the fold change compared to vehicle control. The results are expressed as the mean \pm standard deviation of three separate experiments for each group. Values are significantly different from each control group: ${ }^{*} p<0.05,{ }^{* \star} p<0.01$. 
the experiments.

\section{The Effects of Standardized Extract of Ginkgo biloba on Hormone Concentrations in H295R Cells}

As shown in Figure 2, exposure to EGb761 (10 and $100 \mu \mathrm{g}$ / $\mathrm{mL}$ ) resulted in a significant decrease in $17 \beta$-estradiol (diamond symbol) and testosterone production (square symbol). However, cortisol (triangle symbol) and aldosterone (circle symbol) levels were not significantly changed in H295R cells exposed to 10 and $100 \mu \mathrm{g} / \mathrm{mL}$ of EGb761.

\section{The Effects of Standardized Extract of Ginkgo biloba on Expression of Enzymes Related to Steroidogenesis Pathways}

As shown in Figure 3, the mRNA expression of nine genes, including CYP11A, CYP17A1, 3ß-SD2, CYP21A2, CYP11B1, CYP11B2, CYP19, 17 $\beta-H S D 1$, and 17 $\beta-H S D 4$ were evaluated in H295R cells exposed to EGb761. The mRNA expression of aldosterone/cortisol-related genes such as CYP11A, CYP17A1, $3 \beta$-HSD2, CYP21A2, CYP11B1, CYP11B2, and 17 $\beta$-HSD4 showed no significant changes in response to EGb761 exposure. However, the mRNA expression of CYP19 and 17 $\beta$-HSD1, which are related to $17 \beta$-estradiol and testosterone synthesis, were significantly decreased by EGb761.

\section{Effects of Standardized Extract of Ginkgo biloba on Aromatase Activity}

As shown in Figure 4A, the expression level of the aromatase coding region sequences (CDS) as well as promoter region sequences (Exon PII) were decreased by EGb761. Western blotting confirmed that CYP19 protein synthesis was reduced by
EGb761 exposure (Figure 4B). In addition, aromatase activity measured by both direct and indirect methods was significantly inhibited by exposure to EGb761 (10 and $100 \mu \mathrm{g} / \mathrm{mL}$ ) when compared with control (Figure 4C).

\section{Discussion}

The effects of EGb761 on the synthesis of the four steroid hormones (aldosterone, cortisol, testosterone, and $17 \beta$-estradiol) were evaluated using the human H295R adrenocortical cell line as an in vitro model. In the H295R cells exposed to EGb761 at non-cytotoxic concentrations (10 and $100 \mu \mathrm{g} / \mathrm{mL}$, Figure 1 ), testosterone and $17 \beta$-estradiol were significantly decreased, whereas aldosterone and cortisol were not (Figure 2).

These steroid hormones are synthesized from cholesterol by a series of steroidogenesis pathways, which are dependent on cytochrome P450 enzymes and HSDs [20]. As the first step in the steroidogenesis pathway, cholesterol transported into the inner mitochondrial membrane by StAR [21] is converted into pregnenolone by the cholesterol side-chain cleavage enzyme (CYP450scc), which is known as CYP11A1 [16]. In addition, aldosterone and cortisol are synthesized by regulation of the CYP17A1, 33-HSD2, CYP21A2, and CYP11B1/2 enzymes. In real-time PCR analysis, EGb761 exposure did not affect the expression of these genes (Figure 3), which was consistent with the results showing no change in aldosterone and cortisol levels in H295R cells exposed to EGb761. Although the cortisol level was not significantly changed by EGb761 exposure in this in vitro model system (H295R cell line), several researchers have reported regulation of the cortisol level by EGb761 exposure. Kudolo [22] reported that ingestion of EGb has an effect on the

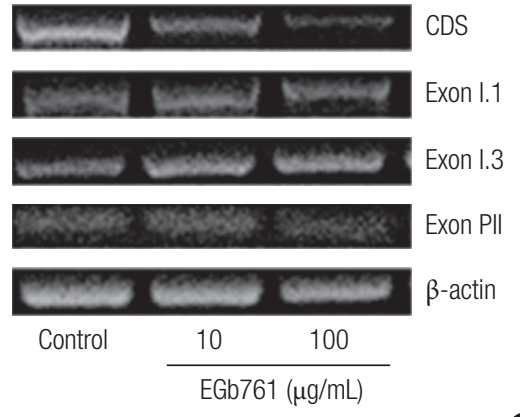

(B)

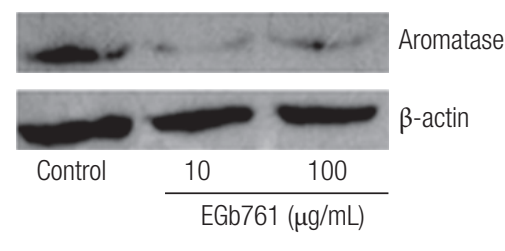

B

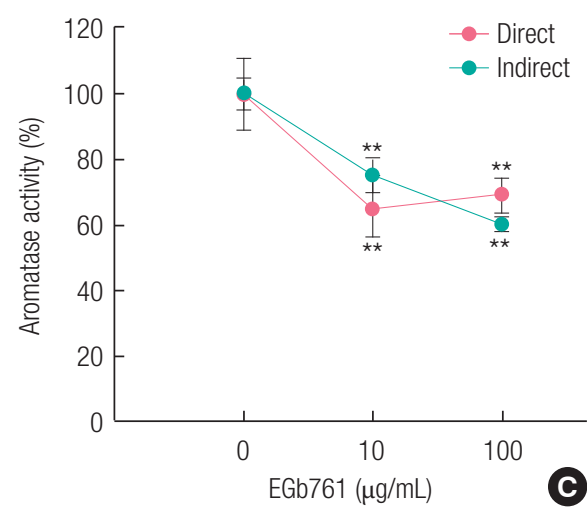

Figure 4. Changes in aromatase (CYP19) expression in H295R cells exposed to standardized extract of Ginkgo biloba (EGb761). (A) The polymerase chain reaction (PCR) products obtained by reverse transcription-PCR [13] were identified by electrophoresis. $\beta$-actin was amplified as an internal control, and the size of the detected PCR products for aromatase CDS, Exon I.1, Exon I.3, Exon Pll, and $\beta$-actin are 987, 113, 339, 113, and $287 \mathrm{bp}$, (B) $50 \mu \mathrm{g}$ of cell lysates were loaded in each lane and analyzed by immunoblotting with aromatase antibody (expected size of the aromatase protein: $53 \mathrm{kDa}$ ), and (C) the aromatase activity was determined using a tritiated water-release assay. H295R cells seeded in 24-well plates were treated with various doses of EGb761 for 24 hours and measured by direct and indirect methods as described in the material and methods section. The results are expressed as the mean \pm standard deviation of three separate experiments for each group. Values are significantly different from the control: ${ }^{\star \star} p<0.01$. CDS, coding region sequences. 


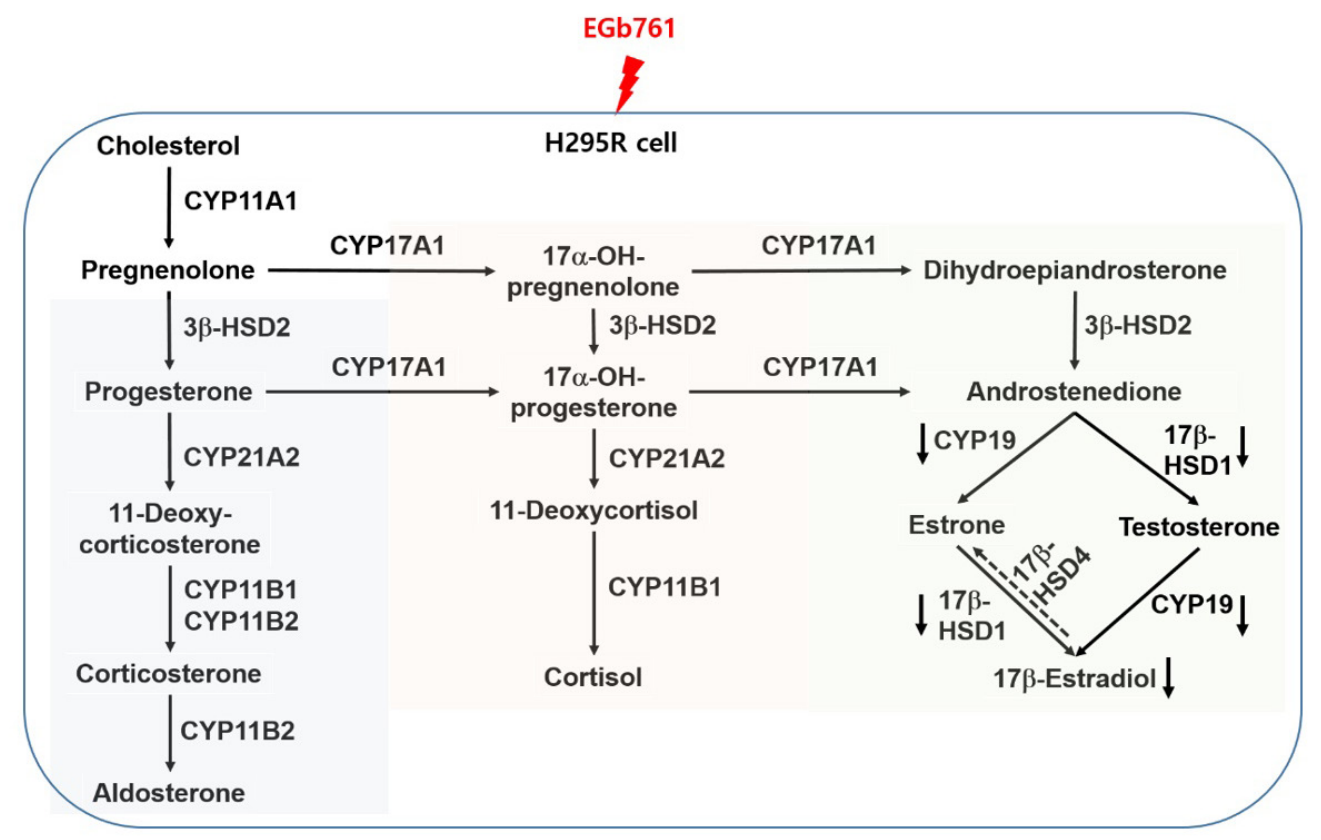

Figure 5. Alterations in steroidogenic gene expression and hormone production in H295R cells exposed to standardized extract of Ginkgo biloba (EGb761) $[16,37,38]$.

hypothalamic-pituitary-adrenal (HPA) axis leading to reduced basal cortisol levels and reduced cortisol production in response to an acute hyperglycemic challenge. In addition, EGb761 may inhibit cortisol release in response to some stress stimuli [23]. The H295R assay used in this study is not intended to identify substances that affect steroidogenesis due to effects on the hypothalamic-pituitary-gonadal and HPA axes [19], which may produce different outcomes between in vitro and in vivo cortisol levels.

In regard to the steroidogenesis pathway (Figure 5), testosterone and $17 \beta$-estradiol levels can be regulated by $17 \beta-H S D 1$ and CYP19. CYP19, which is related to aromatase activity, is the key enzyme responsible for the final rate-limiting reaction in $17 \beta$-estradiol production [24]. 17 $\beta$-HSD1 is the most well characterized of the $17 \beta-H S D$ s catalyzing the reaction from estrone to estradiol [25], whereas $17 \beta-H S D 4$, as an oxidative enzyme, catalyzes the conversion of estradiol to estrone [26]. In this study, EGb761 treatment of H295R cells resulted in a significant reduction of testosterone and $17 \beta$-estradiol levels (Figure 2), which was consistent with the results showing a significant decrease in 17 $\beta$-HSD1 and CYP19 at the concentrations tested (Figure 3). Generally, an increased level of $17 \beta$-estradiol could stimulate the proliferation of the tumor tissue via the estrogen receptor, leading to estrogen-dependent breast cancer. In breast cancer patients that have high 17 $\beta$-HSD1 and CYP19 expression, inhibition of these enzymes may provide therapeutic benefit by depriving the tumor of $17 \beta$-estradiol $[27,28]$. There- fore, we suggest that EGb761 should be evaluated as a therapeutic agent against estrogen-dependent breast cancer, as an inhibitor of $17 \beta-H S D 1$ and CYP19.

EGb761 showed stronger inhibition of CYP19 gene expression than of $17 \beta-H S D 1$ (Figure 3 ). The regulation of the CYP19 gene is controlled by several distinct tissue-specific promoters, which are associated with the placenta (I.1 and 1.2a), skin/normal breast adipose tissue (I.4), endothelial cells (I.7), brain (I.f), bone (I.6), fetal tissues (I.5), adipose tissue (I.4), endometriosis/ovary (II), and breast tumors (I.7 and I.3/II) $[29,30]$. These promoters regulate the transcription of the aromatase gene in human tissues [31]. H295R cells showed aromatase activation by promoter 1.3 /II-specific aromatase transcripts, but did not detect aromatase activity by promoter 1.4 [32]. In this study, H295R cells contained Exon I.1, I.3 and PII, and EGb761 showed a significant decrease of only PII transcript (Figure 4A), which is the most active promoter of aromatase gene expression in H295R cells [32,33]. In previous studies, EGb761 inhibited expression of Exon 1.3/PII in MCF-7 AROM cells [13] and Exon 1.1 in human placenta JEG-3 cells $[11,12]$. These results indicated that EGb761 could regulate tissue-specific transcription of the aromatase gene.

The aromatase activities in H295R cells exposed to EGb761 were significantly inhibited by both the direct and indirect pathways (Figure 4C). Direct interactions with the aromatase enzyme, which had the typical inhibitory action, can include competition of the substance with the ligand, or interference with 
the conversion process of testosterone to $17 \beta$-estradiol. On the other hand, indirect inhibition is associated with gene expression or feedback mechanisms [19]. Direct inhibition of aromatase activity by EGb761 was consistent with the results in MCF7 AROM cells exposed to EGb761 [13]. In addition, the significant inhibition of CYP19 mRNA and protein levels could support indirect inhibition of aromatase activity by EGb761 exposure. Therefore, we suggest that a significant decrease of $17 \beta$-estradiol by EGb761 could be induced by the inhibition of aromatase activity by both the indirect and direct pathways.

Among the chemicals displaying a strong inhibitory effect on hormone secretion, a few have been used clinically in the treatment of adrenal disorders and as steroidogenic inhibitors [34]. Aminoglutethimide, a "generation I" aromatase inhibitor, has been reported to act as a potent inhibitor of CYP450scc. Due to its direct inhibition of CYP450scc and the aromatase enzyme, it was used to treat Cushing's syndrome (a disease that causes an increase in cortisol) and breast cancer, respectively [35,36]. Exposure to aminoglutethimide resulted in a decrease of testosterone and $17 \beta$-estradiol [15]. This mechanism is consistent with the results showing decreased testosterone and $17 \beta$-estradiol production by EGb761, which was expected due to the inhibition of $17 \beta-H S D 1$ and CYP19, respectively. Therefore, these aminoglutethimide results support the assertion that EGb761 also could be an effective natural inhibitor of aromatase as well as steroidogenic enzymes and hormones.

In conclusion, regarding steroidogenesis in H295R cells, EGb761 significantly decreased CYP19 and $17 \beta$-HSD1 gene expression, which are related to sex steroid hormones. Specifically, inhibition of the aromatase enzyme via direct and indirect pathways in H295R cells exposed to EGb761 could induce a significant decrease of $17 \beta$-estradiol secretion. In addition, EGb761 showed no change on the secretion of other steroid hormones such as aldosterone and cortisol. Down-regulation of CYP19/17 $\beta$-HSD1 and depletion of $17 \beta$-estradiol and testosterone have been known to play an important role in hormone dependent breast cancer. Therefore, we suggest that EGb761 should be evaluated as a therapeutic agent in hormone dependent breast cancer because of its specific sex steroid hormone down-regulation.

\section{Acknowledgements}

This study was supported by a grant from the National Research Foundation of Korea funded by the Korea Government (NRF-2013R1A1A2A10060109).

\section{Conflict of Interest}

The authors have no conflicts of interest associated with material presented in this paper.

\section{ORCID}

Mijie Kim https://orcid.org/0000-0002-4715-7641

Yong Joo Park https://orcid.org/0000-0002-0528-6197

Huiyeon Ahn https://orcid.org/0000-0001-5030-1600

Byeonghak Moon ttps://orcid.org/0000-0002-2018-6418

Kyu Hyuck Chung https://orcid.org/0000-0003-4283-0742

Seung Min Oh https://orcid.org/0000-0002-5701-8960

\section{References}

1. Jung KW, Won YJ, Kong HJ, Oh CM, Cho H, Lee DH, et al. Cancer statistics in Korea: incidence, mortality, survival, and prevalence in 2012. Cancer Res Treat 2015;47(2):127-141.

2. Almstrup K, Fernández MF, Petersen JH, Olea N, Skakkebaek NE, Leffers H. Dual effects of phytoestrogens result in u-shaped doseresponse curves. Environ Health Perspect 2002;110(8):743-748.

3. Macedo LF, Sabnis G, Brodie A. Aromatase inhibitors and breast cancer. Ann N Y Acad Sci 2009; 1155:162-173.

4. Mokbel R, Karat I, Mokbel K. Adjuvant endocrine therapy for postmenopausal breast cancer in the era of aromatase inhibitors: an update. Int Semin Surg Oncol 2006;3:31.

5. Janni W, Hepp P. Adjuvant aromatase inhibitor therapy: outcomes and safety. Cancer Treat Rev 2010;36(3):249-261.

6. Ullah MF. Cancer multidrug resistance (MDR): a major impediment to effective chemotherapy. Asian Pac J Cancer Prev 2008; 9(1):1-6.

7. Dubey AK, Shankar PR, Upadhyaya D, Deshpande VY. Ginkgo biloba--an appraisal. Kathmandu Univ Med J (KUMJ) 2004;2(3): 225-229.

8. Oh SM, Chung KH. Estrogenic activities of Ginkgo biloba extracts. Life Sci 2004;74(11):1325-1335.

9. Oh SM, Chung KH. Antiestrogenic activities of Ginkgo biloba extracts. J Steroid Biochem Mol Biol 2006;100(4-5):167-176.

10. Oh SM, Kim HR, Chung KH. Effects of Ginkgo biloba on in vitro osteoblast cells and ovariectomized rat osteoclast cells. Arch Pharm Res 2008;31(2):216-224.

11. Kim MJ, Park YJ, Chung KH, Oh SM. The inhibitory effects of the standardized extracts of Ginkgo biloba on aromatase activity in JEG-3 human choriocarcinoma cells. Phytother Res 2013;27(12): 1756-1762.

12. Park YJ, Choo WH, Kim HR, Chung KH, Oh SM. Inhibitory aromatase effects of flavonoids from Ginkgo biloba extracts on estrogen biosynthesis. Asian Pac J Cancer Prev 2015;16(15):6317-6325.

13. Park YJ, Ahn HY, Kim HR, Chung KH, Oh SM. Ginkgo biloba extract EGb 761-mediated inhibition of aromatase for the treatment of hormone-dependent breast cancer. Food Chem Toxicol 2016; $87: 157-165$. 
14. Gazdar AF, Oie HK, Shackleton $\mathrm{CH}$, Chen TR, Triche TJ, Myers $\mathrm{CE}$, et al. Establishment and characterization of a human adrenocortical carcinoma cell line that expresses multiple pathways of steroid biosynthesis. Cancer Res 1990;50(17):5488-5496.

15. Hecker M, Newsted JL, Murphy MB, Higley EB, Jones PD, Wu R, et al. Isolation and identification of 3-trifluoromethyl-4-nitrophenyl glucuronide from bile of rainbow trout exposed to 3-trifluoromethyl-4-nitrophenol. Toxicol Appl Pharmacol 1973;24(1):114124.

16. Hilscherova K, Jones PD, Gracia T, Newsted JL, Zhang X, Sanderson JT, et al. Assessment of the effects of chemicals on the expression of ten steroidogenic genes in the $\mathrm{H} 295 \mathrm{R}$ cell line using real-time PCR. Toxicol Sci 2004;81(1):78-89.

17. Gracia T, Hilscherova K, Jones PD, Newsted JL, Higley EB, Zhang $\mathrm{X}$, et al. Modulation of steroidogenic gene expression and hormone production of H295R cells by pharmaceuticals and other environmentally active compounds. Toxicol Appl Pharmacol 2007; 225(2):142-153.

18. Lephart ED, Simpson ER. Assay of aromatase activity. Methods Enzymol 1991;206:477-483.

19. Higley EB, Newsted JL, Zhang X, Giesy JP, Hecker M. Assessment of chemical effects on aromatase activity using the H295R cell line. Environ Sci Pollut Res Int 2010;17(5):1137-1148.

20. Hanukoglu I. Steroidogenic enzymes: structure, function, and role in regulation of steroid hormone biosynthesis. J Steroid Biochem Mol Biol 1992;43(8):779-804.

21. Ohlsson A, Ullerås E, Cedergreen N, Oskarsson A. Mixture effects of dietary flavonoids on steroid hormone synthesis in the human adrenocortical H295R cell line. Food Chem Toxicol 2010;48(11): 3194-3200.

22. Kudolo GB. Effect of Ginkgo biloba extract ingestion on plasma total cortisol levels during an oral glucose tolerance test in normal glucose tolerant individuals. Food Nutr Sci 2014;5:1561-1567.

23. Jezova D, Duncko R, Lassanova M, Kriska M, Moncek F. Reduction of rise in blood pressure and cortisol release during stress by Ginkgo biloba extract (EGb 761) in healthy volunteers. J Physiol Pharmacol 2002;53(3):337-348.

24. Wang Y, Ye L, Leung LK. A positive feedback pathway of estrogen biosynthesis in breast cancer cells is contained by resveratrol. Toxicology 2008;248(2-3):130-135.

25. Peltoketo H, Isomaa V, Poutanen M, Vihko R. Expression and regulation of $17 \beta$-hydroxysteroid dehydrogenase type 1.J Endocrinol 1996;150:S21-S30.

26. Luu-The V. Analysis and characteristics of multiple types of human 17beta-hydroxysteroid dehydrogenase. J Steroid Biochem Mol Biol 2001;76(1-5):143-151.
27. Day JM, Tutill HJ, Purohit A, Reed MJ. Design and validation of specific inhibitors of 17 beta-hydroxysteroid dehydrogenases for therapeutic application in breast and prostate cancer, and in endometriosis. Endocr Relat Cancer 2008;15(3):665-692.

28. Cazzaniga M, Bonanni B. Breast cancer chemoprevention: old and new approaches. J Biomed Biotechnol 2012;2012:985620.

29. Mahendroo MS, Mendelson CR, Simpson ER. Tissue-specific and hormonally controlled alternative promoters regulate aromatase cytochrome P450 gene expression in human adipose tissue. J Biol Chem 1993;268(26):19463-19470.

30. Sebastian S, Bulun SE. A highly complex organization of the regulatory region of the human CYP19 (aromatase) gene revealed by the Human Genome Project. J Clin Endocrinol Metab 2001;86(10): 4600-4602.

31. Bulun SE, Lin Z, Imir G, Amin S, Demura M, Yilmaz B, et al. Regulation of aromatase expression in estrogen-responsive breast and uterine disease: from bench to treatment. Pharmacol Rev 2005; 57(3):359-383.

32. Watanabe M, Nakajin S. Forskolin up-regulates aromatase (CYP19) activity and gene transcripts in the human adrenocortical carcinoma cell line H295R. J Endocrinol 2004;180(1):125-133.

33. Sanderson JT, Hordijk J, Denison MS, Springsteel MF, Nantz MH, van den Berg M. Induction and inhibition of aromatase (CYP19) activity by natural and synthetic flavonoid compounds in H295R human adrenocortical carcinoma cells. Toxicol Sci 2004;82(1):7079.

34. Gross BA, Mindea SA, Pick AJ, Chandler JP, Batjer HH. Medical management of Cushing disease. Neurosurg Focus 2007;23(3): E10.

35. Foster AB, Jarman M, Leung CS, Rowlands MG, Taylor GN. Analogues of aminoglutethimide: selective inhibition of cholesterol side-chain cleavage. J Med Chem 1983;26(1):50-54.

36. Johansson K, Ohlsson K, Ingvar C, Albertsson M, Ekdahl C. Factors associated with the development of arm lymphedema following breast cancer treatment: a match pair case-control study. Lymphology 2002;35(2):59-71.

37. Furuta C, Noda S, Li C, Suzuki AK, Taneda S, Watanabe G, et al. Nitrophenols isolated from diesel exhaust particles regulate steroidogenic gene expression and steroid synthesis in the human H295R adrenocortical cell line. Toxicol Appl Pharmacol 2008; 229(1):109-120.

38. von Krogh K, Harjen H, Almås C, Zimmer KE, Dahl E, Olsaker I, et al. The effect of valproate and levetiracetam on steroidogenesis in forskolin-stimulated H295R cells. Epilepsia 2010;51(11):22802288. 